\title{
A Note on Translations
}

Quotations are generally given only in English, except where a particular linguistic or formal point is being made, or when a reader who has German might particularly benefit from having the original. In the case of quotations from Paul Celan himself quotations are given in German and English. Contributors have given sources for published translations used or have provided new translations. These follow the relevant German in square brackets and the primary aim is to provide an accessible working translation. Unless otherwise specified, all other translations are by the author of the chapter.

To avoid unnecessary repetition, however, the titles of Paul Celan's poetry collections are given in the German only. The titles of individual poems are given both in German and English throughout. For ease of reference a list of translations of these main works is included here, and a fuller Select Bibliography is given at the end of the volume.

\section{Poetry collections}

Der Sand aus den Urnen (1948)

Mohn und Gedächtnis (1952)

Von Schwelle zu Schwelle (1955)

Sprachgitter (1959)

Die Niemandsrose (1963)

Atemwende (1967)

Fadensonnen (1968)

Lichtzwang (1970)

Schneepart (1971)

Zeitgehöft (1976)

[The Sand from the Urns]

[Poppy and Memory]

[From Threshold to Threshold]

[Speechgrille]

[The No-One's-Rose]

[Breathturn]

[Threadsuns]

[Lightduress]

[Snowpart]

[Timestead]

\section{Essays}

Der Meridian (Rede anlässlich der

[The Meridian]

Verleihung des Georg-Büchner Preises 1960)

Rede anlässlich der Entgegennahme des

[Bremen Speech] Literaturpreises der Hansestadt Bremen (1958) 
